\title{
Protecting Public Rights on Land Management: A Disjunction between Ideality and Reality
}

\author{
Agus Suprihanto ${ }^{1}$, Farida Patittingi ${ }^{2}$, Anwar Borahima ${ }^{3}$, Sri Susyanti Nur ${ }^{4}$ \\ ${ }^{1}$ Doctoral Candidateat Graduate School Hasanuddin University, Indonesia, ${ }^{2}$ Professor, Department of Civil \\ Law, Faculty of Law, Hasanuddin University, Indonesia, ${ }^{3}$ Professor, Department of Civil Law, Faculty of Law, \\ Hasanuddin University, Indonesia, ${ }^{4}$ Associate Professor, Department of Civil Law, Faculty of Law, Hasanuddin \\ University, Indonesia
}

\begin{abstract}
Land-use systems are characterized by complex interactions between human decision-makers and their rights environment. Mismatches between the scale of human drivers and the impacts of human decisions potentially threaten the public rights as a whole. The research is a normative legal research using a statute, case, and conceptual approaches. The results show that land for management rights can be used for the purposes of conducting their duties or business, and its use can be transferred to third parties with the approval of the holder of management right. In fact, transfer of rights and imposition of mortgage rights can occur even without the permit of the holder of management right. However, when there is default, the creditor experiences obstacles because the National Land Agency rejects to issue a Land Registration Certificate without the holder's permit of management rights, so that collateral cannot be executed. This condition results in the failure to fulfill the principles of justice and legal certainty for creditors and debtors. This provision should be abolished because it contradicts the principle of justice and legal certainty for the parties having an interest in utilizing the management rights land.
\end{abstract}

Keywords: Civil Law; Public Rights; Land Rights; Management.

\section{Introduction}

Land is a fundamental human need (constitutional rights). More important of land for human life, everyone will always try to own and control it. ${ }^{1}$ The population continues to grow causes the need for land to increase, it can be seen from the development of residential, industrial and tourism areas or other needs. Meanwhile, the existing land does not increase or permanent, so requires the State to regulate it so that the State's objectives in promoting the welfare of the Indonesian people can be fulfilled for national development. Land is one of the main assets as a medium for implementing development to create a just and prosperous society. The preamble of the 1945 Constitution affirms one of the objectives of the Indonesian namely to establishes an Indonesian state government that protects the entire Indonesian nation and all Indonesian blood and to promote public welfare. It can be seen that one of the objectives of the Indonesian State is to promote the general welfare and for all Indonesian people. ${ }^{2}$
In order to ensure legal certainty for individuals and legal entities to fulfill business needs and to build anything, it is given the right of the land. ${ }^{3}$ According to Van Vollenhoven, the source of State power over natural resources (including land) is the State is given the authority to regulate everything and it is based on its position has the authority to make legal regulations. ${ }^{4}$ This land registration will produce registration maps, measuring documents for legal certainty including the location, boundaries and width, information and the subject concerned, right status, as well as anything concerns the land and finally issuing a certificate as a powerful evidence. ${ }^{5}$ Land right is a right that give the authority to use land that is given to a person or legal entity. In principle, the purpose of land utilization is to fulfill 2 (two) types of needs i.e cultivation and to build anything.

In practice, the implementation of management rights has experienced significant developments both in terms of its regulation and implementation in the field. ${ }^{6}$ 
Various regulations that regulate the management rights are all at the level of implementing regulations, the rules governing and their explanations are still separate and have not been formed in one law. Management rights which include designation, use, period and compensation provided that the granting of land rights to third parties is conducted by an authorized official based on statutory regulations. In juridical context, the position of the third party is only the "hitchhiking" party such as the holder of temporary land rights due to limited. ${ }^{7}$

Lending made by a Bank as a financing institution should receive legal protection for creditors and recipients, as well as for related parties to receive protection through a legal guarantee institution for all interested parties. In giving credit facilities, requires a sufficient credit guarantee economically and good in juridical, because the condition of debtor may unexpectedly be in a situation of being unable to pay his/ her loan installments (bad credit). If this happens, then the guarantee is expected to guarantee the repayment of debtor's credit.

As the legal phenomena as described above, it can be seen that stakeholders, including notary and the National Land Agency have not implemented procedures according to the applicable regulations in granting, transferring and binding mortgage rights to building use rights on management rights land, due to existing regulations is still unclear and not-codified, so it does not provide legal protection and legal certainty for parties, especially creditors.

\section{Method}

The research is a normative legal research using a statute, case, and conceptual approaches. ${ }^{8}$ Data were analyzed with descriptive qualitative analysis with content analysis. In this study, the authors used the qualitative research method, which (in general) generates words rather than numbers as data for analysis. The approach used is observation and interpretation, which makes these phenomena observable. This paper provides information on the latest trend in research. ${ }^{9}$

Selling and Buying a Plot of Land on Management Right Land: Insights from Indonesia: The procedure for legal actions in transferring (selling, grants, exchanging, pledging or collateralizing and others) of land located on management rights land is almost same as the procedure for buying and selling a plot of land on State land.In selling and buying transaction of land and/or buildings on State land, the parties, namely the seller and the buyer do not need to request approval or permit from any party unless otherwise stipulated by the legislation. It is different if the land are transferred or traded over the land area of management rights, stipulated by Article 34 paragraph (7) jowith Article 54 paragraph (9) Government Regulation No. 40 of 1996 concerning Business Use Rights, Building Use Rights and Land Use Rights before the selling and buying of land use rights for building on management rights land, the parties especially the seller are required to apply for a permit from the holder of the management rights concerned.

As a follow-up to the request, the holder of the management right has the right to issue or reject a permit or recommendation as a form of approval or rejection of the transfer of land and/or buildings to other parties. Permits or recommendations are addressed to the person concerned, the land-owner. However, sometimes when a management right holder gives a permit or recommendation to the Head of the National Land Agency to continue to registration of names change in the documents or certificates of land as traded.

The permits or recommendations by holder of management rights are a real reflection of the implementation of part of the authority of the State' Controlling Rights. In the process of issuing permits or recommendations, the holders of the management rights refer to the terms and conditions set by the holder of the management rights and refer to the contents of the agreed land use surrender agreements as a basis for consideration in the framework of granting permits or recommendations. ${ }^{1}$

Each holder of management rights has its own policies, terms and conditions. They have different administrative management procedures for the land that is controlled with a management right, including the procedure for transferring land rights or assigning them. If the transfer of land will result in inconsistent with the function of land designation and use other than the stipulated provisions or policies, the holder of the management right may reject the application for a permit or recommendation for transfer of the land.

Permits or recommendations for the transfer (selling and buying) of land and/or buildings on management rights are used as tools or instruments to do supervisory (control) function which is the duty and authority of the 
holder of the management rights concerned over land use by third parties. ${ }^{10}$ Through a permit or recommendation agency, the holder of the management right can monitor and prevent parts of management rights land that violate government provisions and policies.

One of the requirements for the transfer (selling and buying) of land and/or buildings on management rights land is to pay the management money concerned. The holders of management rights are authorized to charge administrative fees from holders of land rights on management rights land. The amount of administrative fee is determined based on the full policy by the holder of the management right concerned and notified to the applicant in the permit or recommendation or notified separately.

\section{The Fulfillment of Prudential Banking Principles as an Ideal Model for Protecting Public Rights to} Land: Based on banking principles,credit or financing as provided by banks contains an element of risk, so that in its implementation the bank must considers the principles of credible credit. ${ }^{11}$ These principles are to prevent or reduce the occurrence of risk, therefore the banking sector is required to implement prudential banking principles. The term prudent relates to the supervision and bank management. ${ }^{12}$ The principle of prudent requires banks to always be careful in conduct their business activities, meaning that they must always be consistent in implementing laws and regulations in the banking sector based on professionalism and good faith. $^{13}$

The principle of prudence or also known as the prudential banking principle is an important principle in the practice of banking in Indonesia so that it must be applied or implemented by banks in conduct their business activities. ${ }^{14}$ Also, banks are required to be able to design a good legal relationship with prospective debtors, so as to create good working synergy between creditors and debtors. If the debtor is declared in default, the bank can easily execute the collateral given by the debtor based on the design of the legal relationship that has been previously made. Thus, collateral in their credit is a powerful means of securing credit. ${ }^{15}$

The process of granting credit decisions includes credit initiatives and applications, followed by credit analysis and evaluation, credit negotiations, recommendations for granting credit decisions, credit agreements, binding credit collateral, documentation and credit administration, credit disbursement approval and credit monitoring also against risks that may arise, so as to anticipate by taking measures as protection, legal aspects that strengthen the position of the bank, as well as looking for various alternatives to save credit repayments. Especially in this research regarding Building Use Rights, it is necessary to analyze the collateral that will be used as credit guarantees.

Generally, legal theory states that the act of transferring rights can only be done by legal subjects against legal objects that are privately owned as well. ${ }^{16}$ Because the legal relationship between the subject and the object in the management rights is more public in nature, the legal act of transferring rights (transferring rights directly to another legal subject) is legally prohibited. ${ }^{17}$ If there is an intention to terminate the legal relationship between management rights from the legal subject to another legal subject, that intention is only possible through waiving the right. Especially for investment needs, local governments may apply for management rights to cooperate with investors or third parties. Such management rights can be issued after a certificate is issued which states that the land or land concerned is a management right for the agency concerned.

Such management rights can be utilized by management rights holders including the private sector for or for commercial purposes. One of the forms is by granting Building Use Rights on land under management rights which according to regulations regulates the period of time and other related matters. Management rights are assets of state assets, for the guarantee of Building Use Rights on the land of the management rights that the guarantee is done by the holder of the Building Use rights on the land. The management rights are the Building Use Rights not on the land concerned, so that the provisions related to the prohibition of guaranteeing state assets can be avoided.

Get legal protection is the hope of every legal subject in an agreement. Legal protection is a protection of the rights and obligations of a person where a protection is provided to legal subjects in the form of legal instruments, both preventive and repressive in nature. As a preventive measure, creditors must also conduct credit supervision where the bank must monitor the use of credit, whether the use is in accordance with the provisions. In addition, periodic visits are also held, as well as warnings if the credit being extended has problems. Supervision must also be done over the period of guarantee for Building 
Use Rights so that it does not expire before the credit period. At this stage of supervision, it can be seen that credit quality or what is commonly referred to as earning asset quality.

\section{Conclusion}

Land for management rights can be used for the purposes of conducting their duties or business, and its use can be transferred to third parties with the approval of the holder of management right. In fact, transfer of rights and imposition of mortgage rights can occur even without the permit of the holder of management right. However, when there is default, the creditor experiences obstacles because the National Land Agency rejects to issue a Land Registration Certificate without the holder's permit of management rights, so that collateral cannot be executed. This condition results in the failure to fulfill the principles of justice and legal certainty for creditors and debtors. A judicial review is required of Government Regulation No. 40 of 1996 which stipulates that the transfer of Building Use Rights on management rights land requires prior permit. This provision should be abolished because it contradicts the principle of justice and legal certainty for the parties having an interest in utilizing the management rights land.

Ethical Clearance: No ethical approval is needed.

Source of Funding: Self

\section{Conflict of Interest: Nil}

\section{References}

1. Bakker, L., \& Moniaga, S. The space between: Land claims and the law in Indonesia. Asian Journal of Social Science, 2010; 38 (2), 187-203.

2. Syarif, E. Menuntaskan Sengketa Tanah Melalui Pengadilan Khusus Pertanahan, Jakarta: Kepustakaan Populer Gramedia, 2012; 371.

3. Hutagalung, A.S. Kewenangan Pemerintah di Bidang Pertanahan, Jakarta: Raja Grafindo Persada, 2009; 29.

4. Patinggi, F. Dimensi Hukum Pulau-pulau Kecil di Indonesia, Yogyakarta: Rangkang Education, 2012; 87.
5. Bedner, A., \& Van Huis, S. The return of the native in Indonesian law: Indigenous communities in Indonesian legislation. Journal of the Humanities and Social Sciences of Southeast Asia, 2008; 164 (2), 165-193.

6. Yadav, P., \& Vig, K. Restrictions Imposed by Human Biology in Achievement of Gender Justice as Human Rights. Medico Legal Update, 2020; 20 (1), 26-30.

7. Rahmi, E. Eksistensi Hak Pengelolaan Atas Tanah (HPL) dan Realitas Pembangunan Indonesia. Jurnal Dinamika Hukum, 2010; 10 (3), 339-348.

8. Patton, M.Q., \& Cochran, M. A Guide to Using Qualitative Research Methodology, Medecins Sans Frontieres, UK, 2007; 21.

9. Roth, W.M. Rigorous Data Analysis, Beyond "Anything Goes", Sense Publishers, Taipei, 2015; 36.

10. Krishna, V. V., Kubitza, C., Pascual, U., \& Qaim, M. Land markets, property rights, and deforestation: insights from Indonesia. World Development, 2017; 99, 335-349.

11. Mulyati, E. The Implementation of Prudential Banking Principles to Prevent Debtor with Bad Faith. Padjadjaran Journal of Law, 2018; 5(1), 89108.

12. Gandapradja, P. Dasar dan Prinsip Pengawasan Bank, Jakarta: Gramedia Pustaka Utama, 2004; 21.

13. Hermansyah, Hukum Perbankan Nasonal, Jakarta: Kencana, 2008; 135.

14. Naja, D. Hukum Kredit dan Bank Garansi, Bandung: Citra Aditya Bakti, 2005; 293.

15. Gazali, D.S. \& Usman, R. Hukum Perbankan, Jakarta: Sinar Grafika, 2012; 271.

16. Limpo, S. Y., Patittingi, F., Hasrul, M., \& Yunus, A. Hybridization of indigenous knowledge-based positivistic governance. International Journal of Psychosocial Rehabilitation, 2020; 24(8), 1169811706. doi:10.37200/IJPR/V24I8/PR281144

17. McWilliam, A. Historical reflections on customary land rights in Indonesia. The Asia Pacific Journal of Anthropology, 2006; 7 (1), 45-64. 